Галина Гандзілевська

Сергій Штурхецький

\title{
ПРИКЛАДНА АКМЕОЛОГІЯ для тих, хто прагне успіху
}

\author{
Навчальний посібник \\ для вчителів, журналістів і психологів
}

Острог-2020 


\title{
Прикладна акмеологія для тих, хто прагне успіху
}

\author{
УДК 159.9:070(076) \\ ББК 88
}

Г19

Рекомендовано до друку

вченою радою Національного університету «Острозька академія»

(протокол №13 від 28 травня 2020 року)

\section{Рецензенти:}

Мітчук 0.А., доктор наук із соціальних комунікацій, декан факультету журналістики МЕГУ, доцент, професор кафедри реклами і мови ЗМI

Савелюк Н.М., доктор психологічних наук, доцент, Кременецька обласна гуманітарно-педагогічна академія імені Тараса Шевченка

Плиска Ю. С., доктор педагогічних наук, професор, Національний університет «Острозька академія»

\section{Передмова:}

Калпмаж Р.В., доктор психологічних наук, професор, Національний університет «Острозька академія»

\section{Гандзілевська Г., Штурхецький С.}

Г 19 Прикладна акмеологія для тих, хто прагне успіху [Текст] : навчальний посібник для вчителів, журналістів і психологів / Г. Гандзілевська, С. Штурхецький. - Острог: Видавництво НаУОА, 2020. - 104 с.

$$
\text { ISBN 978-617-7328-88-8 DOI 10.25264/978-617-7328-88-8 }
$$

Навчальний посібник призначений насамперед для слухачів навчальних дисциплін «Психологія життєуспіху», «Прикладна акмеологія», «Журналістика», зокрема, студентів спеціальності «013 Психологія», «053 Початкова освіта», «061 Журналістика», а також для тих, кому цікава проблема досягнення професійного успіху в акмеперіоді. На прикладі соціокультурної адаптації мігрантів запропоновано акмеологічну модель реалізації життєвого сценарію. Особливу увагу у посібнику приділено феномену «професійний сценарій», вивченню чинників процесу відновлення та примноження його акмеологічних ресурсів.

Навчальний посібник пропонує для майбутніх вчителів початкової школи інформаційний ресурс щодо шляхів досягнення професійного успіху, а для майбутніх психологів - практичний інструментарій акмеолога. Майбутні журналісти, окрім кращого розуміння героїв/героїнь своїх публікацій, планування власної кар'єри, зможуть розвинути таку з компетенцій, як здатність до адаптації та дії в новій ситуації. Запропоновано форми, методи й засоби психолого-акмеологічного супроводу вчителя початкової школи у час реформ. Разом з тим посібник буде корисним для всіх, хто прагне досягати вершинного успіху в усіх життєвих сферах.

Посібник побудовано у формі інтерв'ю Сергія Штурхецького у Галини Гандзілевської. Містить інтерв'ю з Г.Гандзілевською на радіопередачі «Теорія всього» (ведучі Д. Шевчук, В. Лебедюк); використано результати докторської дисертації Г. Гандзілевської на тему: "Психологія життєвих сценаріїв у акмеперіоді українських емігрантів», іï роздуми на сторінці в мережі Fасеbоок «Життєві сценарії: теорія і практика».

ISBN 978-617-7328-88-8

DOI 10.25264/978-617-7328-88-8
УДК 159.9:070(076)

ББК 88

(C) Гандзілевська Галина, 2020

(C) Штурхецький Сергій, 2020 


\section{Відчувати повноту життя...}

(передмова)

Важко не погодитись із думкою, що в мінливих (та часто непередбачуваних) умовах сьогодення важливим джерелом досягнення успіху в житті загалом та в професії зокрема стають не тільки знання, навички та низка компетентностей, але й стрімко сформований запит на самопізнання, саморозуміння та саморозвиток, які допомагають успішній адаптації та дії в нових ситуаціях. Корисним інформаційним ресурсом у цій ділянці $є$ представлений навчальний посібник «Прикладна акмеологія для тих, хто прагне успіху», адресно підготовлений для вчителів, психологів та журналістів викладачами Національного університету «Острозька академія» Галиною Гандзілевською та Сергієм Штурхецьким.

Книга, що побудована у формі інтелектуального діалогу між журналістом та науковицею-психологинею, залишає приємний післясмак, адже після ознайомлення з її змістом виникає багато емоційно заряджених рефлексивних запитань до самого себе. Хронотопно-концептуальне поле цих запитань охоплює не тільки власне минуле, теперішнє і майбутнє, але й простягається до досвіду наших предків, сили власного роду, сімейних цінностей, загадкових архетипів, культури, природи... Як наслідок, мотиваційний заряд від відвертих відповідей самому собі про універсальність (схожість з іншими) та унікальність (неповторність) власного Я, його сталість та динамічність, уточнення своєї професійної ідентичності, поява нових поведінкових паттернів. Розуміння, що цінність мають не тільки власні переваги, власні сильні боки, але навіть психологічні бар'єри (захисти, страхи тощо), які за умови відповідної роботи над собою можуть стати нашими ресурсами, допомагає не бути настільки вразливими до нових викликів сьогодення і позитивно налаштуватися на досягнення нових професійних та життєвих цілей.

Приваблює своєю насиченістю психологічний портрет акмеособистості, який ми прочитуємо за представленими результатами наукового дослідження вибірки українських 
Прикладна акмеологія для тих, хто прагне успіху

емігрантів Галини Гандзілевської під керівництвом професора Ігоря Пасічника. Провівши історико-психологічну реконструкцію акмеограм життєвих сценаріїв лідерів літературних об’єднань другої й третьої хвиль еміграції, дослідниця майстерно показала роль морально-етичної, духовної складової, патріотизму, збереження етнічної ідентичності та щирої любові до України у адаптації до зміненого середовища у ті важки часи та, зрештою, у досягненні ними своїх творчих вершин. У цьому плані саме представникам соціономних професій, якими і є вчителі, психологи, журналісти, буде корисно порозмірковувати над представленими ідеями.

Ця праця яскраво віддзеркалює особистості її авторів Галини Гандзілевської та Сергія Штурхецького, які є енергетично зарядженими на успіх, соціально активними, невгамовними і відкритими до нових ідей, до руху, до розвитку, до творчого пошуку, сміливих експериментів, постійного самовдосконалення.

Шановні друзі, упевнена, якщо Ви, читаючи цю працю, відкриєте свій розум і серце, щоб вступити в діалог з їі авторами, дозволите їм говорити з Вами, довірите їм провести Вас захоплюючою мандрівкою стежинами вашого неповторного «життєвого сценарію», на вас чекатимуть несподівані самовідкриття, віднайдення психологічних ресурсів-скарбів та ключів до самоцінності.

Уміти радіти життю, дозволити собі бути успішним, відчувати повноту життя, не боятися вийти із зони комфорту та щось змінити у своєму життєвому сценарії, мріяти і вірити, надіятися і любити - ці своєрідні афірмації будуть супроводжувати Вас упродовж усього читання, надихаючи на самопізнання, на співпрацю з іншими, на пошуки свого акмесередовища та реалізацію свого професійного покликання.

доктор психологічних наук, професор, проректор з навчально-виховної роботи Національного університету «Острозька академія»,

Заслужений працівник освіти Украӥни

Руслана Каламаж 


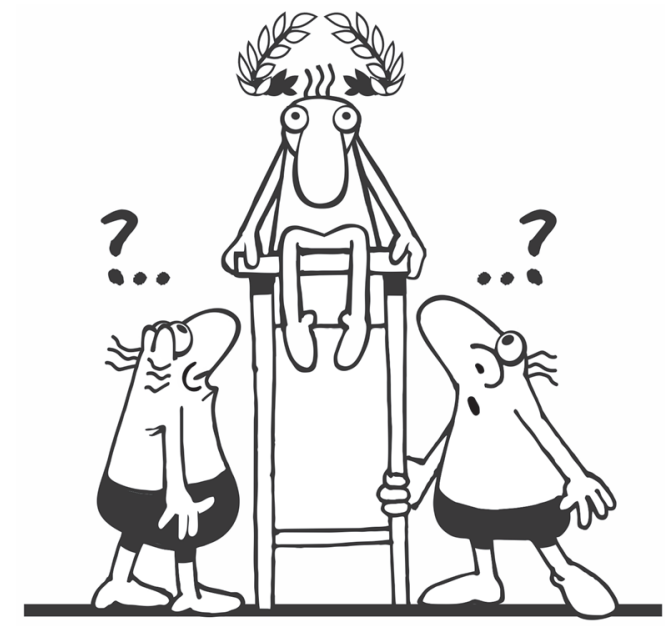

\section{ЧИ ВСІ МОЖУТЬ БУТИ УСПІШНИМИ?}

\section{1. Життєвий сценарій та життєуспіх}

\section{Розділ}

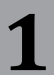

- Коли ми говоримо про успіх, кожна людина, мабуть, уявляє це по-своєму. А що ж розуміють під успіхом та життєуспіхом психологи? Що їм відомо про життєвий успіх?

- Психологічний зміст поняття успіху, відповідно до сучасних досліджень, зокрема Ю. Ільїної, передбачає супровід забезпечення певних потреб відчуттям розвитку, зростання, вірою в свої можливості і в себе. Успіх є бажаним і значимим для особистості результатом діяльності, який досягається за визначений період з передбачуваними допустимими енергетичними або іншими затратами. Стан переживання власного успіху I. Боровинська означує успішністю. Поняття «життєуспіху» часто ототожнюється з поняттям «успіху». Згідно 3 працями Л. Сохань, у вузькому значенні життєуспіх означає досягнення бажаного результату у вирішенні локального життєвого завдання, тоді як у широкому - це оцінка реалізації своєї життєвої програми, свого призначення, а тому пов'язаний з конструюванням і реалізацією життєвого сценарію. 
Прикладна акмеологія для тих, хто прагне успіху

\section{MICT}

Відчувати повноту життя... (передмова) ..................................... 3

Розділ 1. Чи всі можуть бути успішними? ............................... 5

1.1. Життєвий сценарій та життєуспіх ………………………......... 5

1.2. Життєуспіх крізь призму акмеологічного підходу .......... 14

1.3. Прогностична модель життєвого сценарію ......................... 17

Розділ 2. Як досягнути акмеуспіху ............................................. 23

2.1. Акмеперіод: злети і падіння ....................................................... 23

2.2. Психологічний портрет акмеособистості ............................ 26

2.3. Акмеограми і професіограми .................................................... 27

Розділ 3. Життєве виснаження. Як відновитись? .............. 31

3.1. Сценарні установки: психологічний імунітет чи алергія .... 31

3.2. Акмересурси та акмебар'єри вчителів і журналістів:

спільне і відмінне ......................................................................... 34

3.3. Архітектоніка відновлення. 3 чого почати? ........................ 41

Розділ 4. Психолого-акмеологічний супровід у час реформ ..................................................................... 46

4.1. Акмеологічне середовище: чинники та умови його фор-

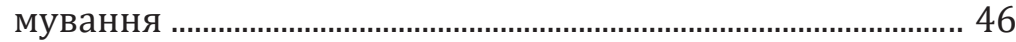

4.2. Техніки досягнення життєуспіху …........................................ 50

4.3. Щоденник самодопомоги: перезавантаження ................... 53

Розділ 5. Секрети життєуспіху …................................................. 57

5.1. Формули життєвого успіху ……………................................... 57

5.2. Акмеограми відомих: життя вдалось ..................................... 60

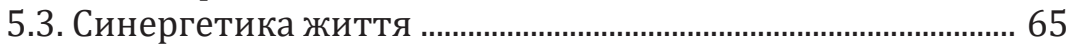

КОРОТКИЙ ТЕРМІНОЛОГІЧНИЙ СЛОВНИК .......................... 68

ДОДАТКИ ..................................................................................... 71

Додаток 1. Акмеограми життєвих сценаріїв та інші матеріали.. 72

Додаток 2. Розмова про акме .......................................................... 87

РЕКОМЕНДОВАНАЛІТЕРАТУРА............................................... 96 
Гандзілевська Галина,

Штурхецький Сергій

\title{
Прикладна акмеологія для тих, хто прагне успіху: навчальний посібник для вчителів, журналістів і психологів
}

\author{
Навчальне видання
}

Ілюстрації до розділів, обкладинка: Павло Шуляк

Верстка: Роман Колодяжний

Коректор: Людмила Алконова

\section{Гандзілевська Г., Штурхецький С.}

Г 19 Прикладна акмеологія для тих, хто прагне успіху [Текст] : навчальний посібник для вчителів, журналістів і психологів / Г. Гандзілевська, С. Штурхецький. - Острог: Видавництво НаУОА, 2020. - 104 с.

ISBN 978-617-7328-88-8

DOI 10.25264/978-617-7328-88-8

УДК 159.9:070(076)

ББК 88

Підп. до др. 15.06 .2020 р.

Формат 60x84/16.

Папір офсетний. Умовн. друк. арк. 6,2.

Гарнітура Cambria.

Наклад 100 прим. Зам. 68.

Видавництво НаУОА.

Свідоцтво суб'єкта видавничої справи РВ № 1 від 8 серпня 2000 року.

вулиця Семінарська, 2, Острог, Рівненська область, 35800;

library@oa.edu.ua

Виготовлено ФОП видавець Свинарчук Р. В.

Свідоцтво суб'єкта видавничої справи РВ № 27 від 29 липня 2004 року.

Тел. (+38068) 6835 800, e-mail: 35800@ukr.net. 